\title{
PENINGKATAN HASIL BELAJAR PESERTA DIDIK MELALUI PENERAPAN MODEL PEMBELAJARAN BERBASIS MASALAH
}

\author{
Lafil Kausar $^{1 *}$, Irdam Idrus ${ }^{1}$, Dewi Jumiarni ${ }^{1}$ \\ ${ }^{1}$ Program Studi Pendidikan Biologi, Fakultas Keguruan dan Ilmu Pendidikan, Universitas Bengkulu \\ email: lafilkausarr22@gmail.com
}

\begin{abstract}
Abstrak
Penelitian ini bertujuan untuk mendeskripsikan aktivitas mengajar guru, aktivitas belajar peserta didik, dan meningkatkan hasil belajar peserta didik dengan menggunakan model Pembelajaran Berbasis Masalah (PBM) di Kelas VIIIA SMPN 05 Mukomuko. Jenis penelitian ini adalah Penelitian Tindakan Kelas dengan metode deskriptif. Penelitian ini terdiri dari dua siklus, masing-masing siklus terdiri dari 4 tahap yaitu: tahap perencanaan, pelaksanaan, pengamatan dan refleksi. Subjek penelitian ini adalah guru dan seluruh peserta didik kelas VIIIA SMPN 05 Mukomuko. Instrumen penelitian yang digunakan adalah lembar tes dan lembar observasi, lembar observasi terdiri dari lembar observasi guru dan peserta didik. Pada siklus I aktivitas mengajar guru diperoleh skor rata-rata yaitu 29 (Baik) dan pada siklus II skor aktivitas guru menjadi 32 (Baik). Pada siklus I aktivitas belajar peserta didik diperoleh skor rata-rata yaitu 29 (Baik) dan pada siklus II skor aktivitas belajar peserta didik menjadi 32 (Baik). Hasil analisis persentase ketuntasan belajar peserta didik pada siklus I yaitu 66,67\% (tidak tuntas) dan pada siklus II meningkat menjadi 88,89\% (tuntas). Dari hasil penelitian dapat disimpulkan bahwa model PBM dapat meningkatkan aktivitas guru dan peserta didik serta hasil belajar peserta didik kelas VIIIA SMPN 05 Mukomuko.
\end{abstract}

Kata Kunci: Pembelajaran Berbasis Masalah, Aktivitas dan Hasil Belajar.

\begin{abstract}
This research aims to describe teacher's teaching activity, students' learning activity and improving students' learning outcomes using Problem Based Learning model (PBL) at VIIIA of SMPN 05 Mukomuko. This type of research was a Classroom Action Research with descriptive method. This research consist of two cycles, where each cycle consist of 4 steps, they were: planning, implementation, observation and reflection. The subject of this research was teacher and all students at VIIIA of SMPN 05 Mukomuko. The research instruments used were test and observation sheets, where the observation sheet consist of teacher's and students' observation. In cycle I, it was obtained the average score of teacher's teaching activity was 29 (good) and in cycle II, the teacher's activity score becomes 32 (good). In cycle I, it was obtained students' learning activity was 29 (good) and in cycle II, the students' activity score becomes 32 (good). The results of analysis of students' learning completeness in cycle I was $66.67 \%$ (incomplete) and in cycle II improves to $88.89 \%$ (complete). From the results, it is concluded that PBL model can improve teacher's and students' activity also students' learning outcomes at VIIIA of SMPN 05 Mukomuko.
\end{abstract}

Keywords: Problem Based Learning, Activity and Learning Outcomes 


\section{PENDAHULUAN}

Sumber daya manusia merupakan suatu aset atau sumber dalam membangun suatu bangsa. Peningkatan kualitas suatu bangsa sesungguhnya bertumpu pada peningkatan sumberdaya manusianya dan hanya akan dapat tercapai salah satunya melalui pendidikan. pendidikan berfungsi mengembangkan kemampuan dan membentuk watak serta peradaban bangsa yang bermartabat dalam rangka mencerdaskan kehidupan bangsa dan bertujuan untuk mengembangkan potensi peserta didik agar menjadi manusia yang beriman dan bertakwa kepada Tuhan Yang Maha Esa, berakhlak mulia, sehat, berilmu, cakap, kreatif, mandiri, dan menjadi warga negara yang demokratis serta bertanggung jawab (Undangundang Nomor 20 Tahun 2003).

Peningkatan kualitas pendidikan dapat dilakukan dengan melakukan perubahan dan pengembangan sistem pendidikan seperti kurikulum. Kurikulum adalah seperangkat rencana dan pengaturan mengenai tujuan, isi, dan bahan pelajaran serta cara yang digunakan sebagai pedoman penyelenggaraan kegiatan pembelajaran untuk mencapai tujuan pendidikan tertentu (BSNP, 2006). Pemerintah melalui Kementerian Pendidikan dan Kebudayaan telah mengembangkan kurikulum baru sebagai koreksi dan sekaligus penyempurnaan dari kurikulum sebelumnya yaitu KTSP menjadi Kurikulum 2013.

Kurikulum 2013 adalah suatu kurikulum yang bertujuan untuk mempersiapkan manusia Indonesia agar memiliki kemampuan hidup sebagai pribadi warga negara yang beriman, produktif, kreatif dan efektif serta mampu berkontribusi pada kehidupan bermasyarakat, berbangsa, bernegara, dan peradaban dunia. Sehubungan dengan itu, Kurikulum 2013 menerapkan pendekatan saintifik dalam pembelajaran (Permendikbud Nomor 58 Tahun 2014).
Pendekatan saintifik pada kurikulum 2013 digunakan untuk seluruh mata pelajaran, seperti mata pelajaran IImu Pengetahuan Alam (IPA). Mata pelajaran IPA di SMP tergolong dalam kelompok mata pelajaran IImu Pengetahuan dan Teknologi. Tujuan kelompok mata pelajaran IImu Pengetahuan dan Teknologi adalah untuk mengembangkan logika, kemampuan berpikir dan analisis peserta didik (Permendikbud Nomor 23 Tahun 2006).

Keberhasilan proses pembelajaran IPA dapat dilihat dari hasil belajar peserta didik selama kurun waktu tertentu. Tujuan pembelajaran IPA yang ingin dicapai dari proses pendidikan adalah hasil belajar peserta didik yang meliputi ranah kognitif, afektif, dan psikomotor (Nurhidayat, 2011).

Berdasarkan hasil observasi awal dan wawancara dengan guru IPA kelas VIIIA SMPN 05 Mukomuko, diperoleh informasi sebagai berikut: 1) Kegiatan pembelajaran masih didominasi oleh guru, 2) Guru masih kurang melibatkan peserta didiknya dalam memecahkan masalah-masalah yang timbul di kehidupan nyata mereka dan mengaitkan masalah-masalah tersebut dengan materi pembelajaran, 3) Kurangnya minat peserta didik dalam proses kegiatan pembelajaran. Beberapa permasalah tersebut berdampak pada hasil belajar peserta didik yang kurang maksimal. Dari 27 orang peserta didik yang mencapai ketuntasan belajar hanya 17 orang (62\%) yang memenuhi nilai KKN. Masih banyak peserta didik yang belum mencapai Kriteria Ketuntasan Minimal (KKM) yaitu 75.

Maka untuk mengatasi masalah tersebut dilakukan kolaborasi guru IPA dengan peneliti yaitu dengan melaksanakan Penelitian Tindakan Kelas (PTK) untuk meningkatkan hasil belajar peserta didik. Penelitian Tindakan Kelas yang disepakati antara guru dan peneliti adalah dengan menerapkan model pembelajaran berbasis masalah (PBM). 
Pembelajaran Berbasis Masalah merupakan inovasi dalam pembelajaran karena dalam PBM, kemampuan berpikir peserta didik betul-betul dioptimalisasikan melalui proses kerja kelompok atau tim yang sistematis, sehingga peserta didik dapat memperdayakan, mengasah, menguji, dan mengembangkan kemampuan berpikirnya secara kesinambungan (Rusman, 2014). Tujuan dari penelitian ini adalah untuk mendeskripsikan aktivitas mengajar guru, aktivitas belajar peserta didik dan hasil belajar IPA kelas VIIIA SMPN 05 Mukomuko pada materi sistem pernapasan melalui penerapan model pembelajaran berbasis masalah.

\section{METODE}

Penelitian ini merupakan penelitian tindakan kelas (PTK) dengan metode deskriptif yang dilakukan dalam dua siklus, setiap siklus terdiri dari tahap perencanaan, pelaksanaan, pengamatan, dan refleksi. Penelitian dilaksanakan pada semester genap tahun ajaran 2017/2018 di SMPN 05 Mukomuko. Peran peneliti pada penelitian ini adalah sebagai guru biologi yang mengajar peserta didik pada materi sistem pernapasan.

Subjek dalam penelitian ini adalah guru sebagai peneliti dan peserta didik kelas VIIIA SMPN 05 Mukomuko tahun ajaran 2017/2018 yang berjumlah 27 orang peserta didik yang terdiri dari 12 peserta didik laki-laki dan 15 peserta didik perempuan.

Teknik pengumpulan data yang digunakan dalam penelitian ini adalah observasi dan tes. Instrumen yang digunakan berupa lembar observasi aktivitas guru, aktivitas peserta didik dan lembar tes hasil belajar.

Data observasi aktivitas guru, aktivitas peserta didik dan hasil belajar yang telah diperoleh digunakan untuk merefleksikan tindakan yang telah dilakukan dan diolah secara deskriptif dengan menghitung:

\section{a. Analisis data hasil observasi aktivitas guru dan aktivitas peserta didik}

Data hasil observasi aktivitas guru dan aktivitas peserta didik pada siklus I dan siklus II dianalisis dengan mencari rerata dengan rumus sebagai berikut:

Rata-Rata Skor $=\frac{\text { jumlah skor }}{\text { jumlah observer }}$ (Sudijono, 2015).

Hasil penilaian lembar observasi dikategorikan kedalam 3 kriteria yang dapat dilihat pada Tabel 1.

Tabel 1. Kategori Penilaian Aktivitas Guru Dan Aktivitas Peserta Didik

\begin{tabular}{cc}
\hline Rentang skor & Kategori Penilaian \\
\hline $11-17$ & Kurang \\
$18-24$ & Cukup \\
$25-33$ & Baik \\
\hline
\end{tabular}

\section{b. Analisis data hasil belajar}

Data tes hasil belajar yang sudah diperoleh dari setiap siklus dianalisis secara deskriptif untuk mengetahui nilai rata-rata hasil belajar dan persentase ketuntasan belajar klasikal.

\section{1) Rerata dihitung dengan menggunakan rumus}

$$
\mathrm{X}=\frac{\Sigma X}{N} \text { (Sudijono, 2015). }
$$

Keterangan :

$X \quad$ : Nilai rata- rata peserta didik

$\Sigma X \quad$ : Jumlah nilai peserta didik

$\mathrm{N}$ : Jumlah peserta didik
2) Persentase Ketuntasan belajar
$K B=\frac{N}{S} \times 100 \%$ (Sudijono, 2015).
Keterangan:
KB : Ketuntasan Belajar Klasikal
$\mathrm{N}$ : Jumlah peserta didik yang mendapat nilai $\geq 75$
$S \quad$ : Jumlah peserta didik




\section{HASIL DAN PEMBAHASAN}

Berdasarkan hasil penelitian yang telah dilakukan data hasil observasi aktivitas mengajar guru dan aktivitas belajar peserta didik dapat dilihat pada Tabel 2.

Tabel 2. Hasil Observasi Aktivitas Guru dan Peserta Didik

\begin{tabular}{ccccc}
\hline Aktivitas & \multicolumn{2}{c}{ Siklus I } & \multicolumn{2}{c}{ Siklus II } \\
\cline { 2 - 5 } & Rerata & Kriteria & Rerata & Kriteria \\
\hline Aktivitas & 29 & Baik & 32 & Baik \\
guru & & & & \\
$\begin{array}{c}\text { Aktivitas } \\
\text { peserta } \\
\text { didik }\end{array}$ & 29 & Baik & 32 & Baik \\
\hline
\end{tabular}

Sedangkan hasil belajar peserta didik pada siklus I dan siklus II dengan penerapan model PBM pada materi sistem pernapasan, dapat dilihat pada Tabel 3.

Tabel 3. Rata-rata Nilai Hasil Belajar Peserta Didik Siklus I dan Siklus II

\begin{tabular}{ccccc}
\hline Siklus & $\begin{array}{c}\text { Rata- } \\
\text { rata }\end{array}$ & $\begin{array}{c}\text { Jumlah } \\
\text { peserta } \\
\text { didik yang } \\
\text { Mendapat } \\
\text { nilai } \geq 75\end{array}$ & $\begin{array}{c}\text { Persentase } \\
\text { ketuntasan } \\
\text { belajar }\end{array}$ & $\begin{array}{c}\text { Kriteria } \\
\text { ketuntasan } \\
\text { belajar } \\
\text { klasikal }\end{array}$ \\
\hline 1 & 77,77 & 18 & $66,67 \%$ & $\begin{array}{c}\text { Belum } \\
\text { Tuntas }\end{array}$ \\
2 & 85,5 & 24 & $88,89 \%$ & Tuntas \\
\hline
\end{tabular}

Data pada Tabel 2, menunjukkan terjadi peningkatan aktivitas guru maupun aktivitas peserta didik dari siklus I ke siklus II. Penerapan model PBM secara keseluruhan telah tergolong ke dalam kriteria baik, namun masih terdapat kekurangan yang dilakukan oleh guru dan peserta didik pada saat melaksanakan tiap tahap-tahap model PBM yaitu sebagai berikut:

Pada tahap orientasi peserta didik kepada masalah ada beberapa kegiatan guru yang meliputi: menjelaskan tujuan pembelajaran, menjelaskan logistik yang dibutuhkan, mengajukan fenomena atau cerita untuk memunculkan masalah, dan memotivasi peserta didik untuk terlibat dalam pemecahan masalah.

Kekurangan yang ditemukan yaitu pada aspek kedua menjelaskan logistik yang dibutuhkan dalam pembelajaran seperti lembar kerja peserta didik (LKPD). Pada siklus I kegiatan guru dan peserta didik masih belum optimal (kriteria cukup) karena guru hanya menjelaskan secara umum mengenai LKPD dan tidak menuliskannya di papan tulis sehingga peserta didik mengalami kesulitan sangat mengerjakan LKPD. Namun setelah dilakukan refleksi pada siklus II kegiatan guru dapat berjalan dengan optimal (kriteria baik) guru menjelaskan dan menuliskan di papan tulis halhal yang harus dikerjakan oleh peserta didik pada LKPD dan perserta didik memperhatikan serta mencatat penjelasan tersebut. Hal ini telah sesuai dengan pendapat Hosnan (2014), bahwa prosedur eksperimen atau percobaan salah satunya yaitu memberikan penjelasan kepada peserta didik tentang alat-alat serta bahan-bahan yang akan dipergunakan dalam eksperimen.

Kekurangan juga ditemukan pada aspek ketiga yaitu mengajukan fenomena atau cerita untuk memunculkan masalah. Kegiatan guru dan peserta didik pada siklus I masih belum optimal (kriteria cukup) karena masalah yang disampaikan guru hanya menyangkut dua tujuan pembelajaran yaitu menjelaskan tahaptahap inspirasi dan ekspirasi pada pernapasan manusia dan mendemonstrasikan alat peraga pernapasan manusia sedangan tujuan pembelajarannya yaitu menjelaskan macam organ penyusun sistem pernapasan pada manusia tidak tampak pada kegiatan ini. Saat guru mengajukan pertanyaan hanya sebagian peserta didik yang menjawab sesuai dengan fenomena atau cerita yang disampaikan guru sebelumnya. Setelah dilakukan refleksi pada siklus II kegiatan guru dan peserta didik dapat berjalan dengan optimal (kriteria baik) karena 
fenomena yang disampaikan guru untuk memunculkan masalah pada siklus II telah menyangkut keseluruhan tujuan pembelajaran dan peserta didik menjawab sesuai dengan fenomena atau cerita yang disampaikan guru. Kegiatan yang dilakukan guru dan peserta didik pada aspek orientasi peserta didik kepada masalah ini sesuai dengan pendapat Sani (2014), PBM merupakan pembelajaran yang penyampaiannya dilakukan dengan cara menyajikan suatu permasalahan, mengajukan pertanyaan-pertanyaan, memfasilitasi penyelidikan, dan membuka dialog. Permasalahan yang dikaji hendaknya merupakan permasalahan kontekstual yang ditemukan oleh peserta didik dalam kehidupan sehari-hari.

Pada tahap mengorganisasikan peserta didik untuk belajar terdapat beberapa kegiatan guru yang meliputi: membantu peserta didik mendefinisikan tugas belajar yang berhubungan dengan masalah pada sistem pernapasan, mengorganisaikan tugas belajar peserta didik yang berhubungan dengan masalah pada sistem pernapasan, dan membimbing peserta didik dalam pembagian kelompok.

Kekurangan yang ditemukan pada aspek pertama yaitu membantu peserta didik mendefinisikan tugas belajar yang berhubungan dengan masalah pada sistem pernapasan. Kegiatan guru dan peserta didik pada aspek ini di siklus I masih belum optimal (kriteria cukup) karena guru hanya menjelaskan secara umum tentang definisi tugas belajar peserta didik seperti berbagi tugas dalam proses pemecahan masalah sehingga peserta didik kurang memahami apa yang akan dilakukan pada masing-masing peserta didik di setiap kelompok. Namun setelah dilakukan refleksi pada siklus II kegiatan guru dan peserta didik telah optimal (kriteria baik) karena guru sudah menjelaskan definisi tugas belajar secara rinci dan menginstruksikan ketua kelompok untuk membagi tugas anggota kelompoknya dalam proses memecahkan masalah sehingga seluruh peserta didik memahami apa yang harus dilakukan di kelompoknya.

Kegiatan yang dilakukan guru dalam mengorganisasikan peserta didik pada siklus I dan siklus II ini telah sesuai dengan pendapat Trianto (2011), yang menyatakan bahwa model pembelajaran berbasis masalah membutuhkan pengembangan keterampilan kerja sama di antara peserta didik dan saling membantu untuk menyelidiki masalah secara bersama. Pengorientasian peserta didik ini berupa pembentukan kelompok untuk mengembangkan kemampuan peserta didik bersosialisasi dengan teman-temannya, sehingga dapat mengembangkan pemikirannya.

Pada tahap membimbing penyelidikan individual maupun kelompok ada beberapa kegiatan guru yang meliputi: Mendorong peserta didik secara kelompok mengumpulkan informasi yang sesuai, dan membimbing peserta didik secara individual untuk aktif ikut memecahkan masalah yang telah disajikan. Kegiatan yang dilakukan guru dalam membimbing penyelidikan individual maupun kelompok dari keseluruhan aspek telah mendapatkan kriteria baik pada siklus I dan siklus II dan sesuai dengan pendapat Khalifah (2013), yang menyatakan bahwa guru membantu peserta didik mentransfer pengetahuan mereka untuk memahami masalah dalam kehidupan nyata serta mampu merangsang perkembangan kemajuan berfikir peserta didik untuk menyelesaikan masalah yang dihadapi secara tepat.

Pada tahap mengembangkan dan menyajikan hasil karya, aktivitas guru yaitu membantu peserta didik dalam merencanakan dan menyiapkan hasil karya yang berupa laporan kelompok serta membantu mereka untuk berbagi tugas dengan temannya. Kegiatan yang dilakukan guru dan peserta didik pada siklus I dan siklus II masih belum optimal 
(kriteria cukup), hal ini disebabkan tidak seluruh kelompok dapat mempresentasikan hasil diskusinya di depan kelas akibat keterbatasan waktu dan penggunaan waktu yang terlalu lama untuk berdiskusi. Manajemen waktu pada pembelajaran berbasis masalah harus sangat di perhatikan karena setelah peserta didik melakukan diskusi, meraka harus menyampaikan hasil karyanya untuk di tanggapi oleh kelompok lain, ini bertujuan untuk mengukur sebatas mana kemampuan kelompok tersebut. Hal ini sesuai dengan Permendikbud Nomor 58 Tahun 2014, yang menyatakan bahwa pembelajaran IPA sebaiknya dilaksanakan dengan menerapkan konsep IPA yang dipelajari dengan mengajukan pertanyaan, memecahkan permasalahan dengan menggunakan pengetahuan yang dimilikinya, merencanakan dan membuat keputusan, melakukan kegiatan diskusi kelompok, dan memperoleh penilaian yang transparan/ hasil karya yang baik.

Pada tahap menganalisis dan mengevaluasi proses pemecahan masalah kegiatan guru yaitu membantu peserta didik untuk melakukan refleksi atau evaluasi terhadap penyelidikan yang mereka lakukan pada materi sistem pernapasan. Sedangkan kegiatan peserta didik yaitu melakukan refleksi atau evaluasi terhadap penyelidikan mereka dan proses-proses yang mereka gunakan. Kegiatan yang dilakukan guru dan peserta didik pada siklus I dan siklus II telah optimal (kriteria baik), guru telah membimbing peserta didik dalam mengevaluasi kegiatan pembelajaran yang dilakukan dengan melakukan tanya jawab pada peserta didik mengenai konsep-konsep yang belum dipahami dan setelah tanya jawab guru dan peserta didik membuat kesimpulan dari kegiatan pembelajaran secara bersamasama. Hal ini sesuai dengan pernyataan Rusman (2014), yang menyatakan bahwa peran peserta didik secara khusus adalah berpartisipasi dalam pengembangan serta mengevaluasi kemajuan diri sendiri.
Peningkatan aktivitas mengajar guru dan aktivitas belajar peserta didik dari siklus I ke siklus II juga diiringi dengan peningkatan Hasil belajar peserta didik. Pada Tabel 3, persentase ketuntasan belajar klasikal peserta didik pada siklus I yaitu $66,67 \%$ meningkat pada siklus II menjadi $88,89 \%$. Menurut Dimyati (2009), hasil belajar merupakan hasil dari suatu interaksi tindak belajar dan tindak mengajar dan merupakan tujuan akhir dilaksanakannya kegiatan pembelajaran di sekolah.

Sehingga dengan diterapkannya model PBM guru lebih memberikan kesempatan kepada peserta didik untuk aktif pada saat pembelajaran seperti mengumpulkan data, mengolah data dan memecahkan masalah untuk memperoleh hasil berupa pemahaman dalam materi yang dipelajari. Selain itu peserta didik juga diberi kesempatan untuk melakukan percobaan dan diskusi yang kontekstual dengan masalah sehari-hari untuk memperoleh pengalaman dan mengubah tingkah laku. Hal ini sesuai dengan pendapat Arends (1997) dalam Trianto (2014), bahwa pembelajaran berbasis masalah merupakan suatu pendekatan pembelajaran dimana peserta didik mengerjakan permasalahan yang autentik dengan maksud untuk menyusun pengetahuan mereka sendiri, mengembangkan inkuiri dan keterampilan tingkat tinggi, mengembangkan kemandirian dan percaya diri.

Hasil yang didapatkan ini sesuai juga dengan penelitian yang dilakukan oleh Suryono (2015), yang menyatakan bahwa dengan penerapan model pembelajaran berbasis masalah dapat meningkatkan hasil belajar IPA materi sistem pernapasan pada manusia kelas XI IPA4 SMAN 1 Kota Bengkulu dengan ketuntasan klasikal $74,2 \%$ menjadi $87,09 \%$. Selanjutnya penelitian oleh Kurniawan (2017), yang menyatakan bahwa dengan penerapan model pembelajaran berbasis masalah dapat meningkatkan hasil belajar peserta didik kelas 
VIIIE SMPN 2 Kota Bengkulu dengan ketuntasan klasikal $77,78 \%$ menjadi $86,11 \%$.

\section{PENUTUP}

\section{Simpulan}

Berdasarkan hasil penelitian tindakan kelas VIIIA SMPN 05 Mukomuko dengan menerapkan model Pembelajaran Berbasis Masalah pada materi sistem pernapasan yang dilakukan dalam dua siklus dapat disimpulkan bahwa:

1. Pembelajaran IPA Biologi pada materi sistem pernapasan dengan menerapkan model PBM dapat meningkatkan aktivitas mengajar guru dan aktivitas belajar peserta didik kelas VIIIA SMPN 05 Mukomuko pada siklus I dengan rerata skor aktivitas guru dari 29 mengalami peningkatan di siklus II menjadi 32 dan rerata aktivitas peserta didik dari 29 menjadi 32.

2. Pembelajaran IPA Biologi pada materi sistem pernapasan dengan menerapkan model PBM dapat meningkatkan hasil belajar peserta didik kelas VIIIA SMPN 05 Mukomuko yaitu dengan ketuntasan belajar klasikal dari $66,67 \%$ menjadi $88,89 \%$.

3.

Saran

1. Untuk peneliti selanjutnya diharapkan peneliti lebih mengoptimalkan tiap sintaks model PBM dan dapat mengatur waktu dengan sebaik mungkin agar mendapatkan hasil yang maksimal baik pada aktivitas mengajar guru dan aktivitas belajar peserta didik serta hasil belajar.

2. Guru mata pelajaran IPA Biologi kelas VIIIA SMPN 05 Mukomuko dapat menggunakan model PBM sebagai suatu alternatif untuk diterapkan pada pembelajaran IPA Biologi sebagai upaya meningkatkan hasil belajar peserta didik.

\section{DAFTAR PUSTAKA}

Badan Standar Nasional Pendidikan (BSNP). 2006. Panduan Penyusunan Kurikulum Tingkat Satuan Pendidikan Jenjang Pendidikan Dasar dan Menengah. Jakarta: BSNP.

Dimyati dan Mudjiono. 2009. Belajar dan Pembelajaran. Jakarta: Rineka Cipta.

Hosnan. 2014. Pendekatan Saintifik dan Kontekstual Dalam Pembelajaran Abad 21. Bogor: Ghalia Indonesia.

Khalifah, N.U. 2013. Penerapan Model pembelajaran Berbasis Masalah(PBM) Untuk Meningkatkan Aktivitas dan Hasil Belajar Biologi Peserta didik Kelas VIII 3 SMP 21 Kota Bengkulu. Skripsi Tidak Dipublikasi. Bengkulu: UNIB

Kurniawan, D.A. 2017. Penerapan Model Pembelajaran Berbasis Masalah Dengan Pendekatan Saintifik Untuk Meningkatkan Hasil Belajar IPA Materi Sistem Respirasi Pada Peserta didik Kelas VIIIE SMPN 2 Kota Bengkulu: UNIB. Tidak Dipublikasi

Nurhidayat, A. 2011. Pengaruh Penerapan Model Pembelajaran Kooperatif Tipe Group Investigation Terhadap Aktivitas dan Penguasaan Konsep Pada Pokok Bahasan Archaebacteria dan Eubancteria Peserta didik Kelas $X$ SMAN 2 Bantul. Skripsi tidak diterbitkan UIN SUKA.

Permendikbud Nomor 58 Tahun 2014 tentang Kerangka Dasar dan Struktur Kurikulum SMP/MTs (salinan).

Permendikbud Nomor 23 Tahun 2006 tentang Standar Kompetensi Lulusan untuk Satuan Pendidikan Dasar dan Menengah (salinan).

Rusman. 2014. Model-model pembelajaran mengembangkan profesionalisme 
Sekolah

Menengah

Pertama/Madrasah tsanawiyah.

Jakarta: Kementerian Pendidikan dan Kebudayaan.

Sani, R.A. 2014. Pembelajaran Saintifik untuk Implementasi Kurikulum 2013. Jakarta: PT Bumi Aksara

Sudijono, A. 2016. Pengantar Statistik Pendidikan. Jakarta: Rajawali Pers

Suryono, E. 2015. Penerapan Model Pembelajaran Berbasis Masalah (PBM) Untuk Meningkatkan Hasil Belajar Biologi Materi Sistem Pernapasan pada
Manusia Peserta didik Kelas Xi Ipa4 Sma N 1 Kota Bengkulu. Skripsi Tidak dipublikasi. Bengkulu: UNIB.

Trianto. 2011. Penelitian Tindakan Kelas. Jakarta: Tim Prestasi Pustaka

Trianto. 2014. Mendesain Model Pembelajaran Inovatif, Progresif, dan Kontekstual. Jakarta : Prenadamedia Group.

Undang-Undang Republik Indonesia Nomor 20 Tahun 2003 tentang Sistem Pendidikan Nasional. 2003. Jakarta: Depdiknas. 